\title{
A MODEL FOR PERSONAL FINANCIAL PLANNING TOWARDS RETIREMENT
}

\author{
Teresa C. HERRADOR-ALCAIDE (D) 1*, Montserrat HERNÁNDEZ-SOLÍS², \\ Gabriela TOPA (D) 3 \\ 1, 2 Faculty of Economics and Business, National Distance Education University (UNED), \\ Madrid, Spain \\ ${ }^{3}$ Faculty of Psychology, National Distance Education University (UNED), Madrid, Spain
}

Received 27 June 2020; accepted 20 November 2020

\begin{abstract}
One problem for sustainability of systems pensions is how people without specialized financial training could manage their resources and their actual personal intentions towards retirement. Research objective is to analyse the relationship among several factors that affect the behaviour towards retirement, the financial management practices and the financial resources, by carrying out a structural equation model (SEM) that was tested in Spanish workers sample in three phases. The influence of financial literacy, financial retirement objectives, optimism on retirement, tolerance to financial risk, and the commitment to financial planning at time 1, are analysed as explanatory variables of financial management practices at time 2. Financial resources for retirement at time 3 are explained by financial management practices.

According to results, the model can predict the $36 \%$ of the variance of financial management practices and $53 \%$ of the variance of financial resources for retirement. Thus, the model can be used for checking of knowledge of the personal financial behaviour before retirement, what enables a better personal financial planning. It would be possible to apply a model based on self-assessment in order to implement a complementary financial planning that would allow to maintain the welfare during retirement.
\end{abstract}

Keywords: retirement, behaviour towards retirement, financial management practices, financial resources, personal financial behaviour, personal financial planning, welfare during retirement, pensions, self-knowledge for retirement.

JEL Classification: J14, J26, D14.

\section{Introduction}

Financial behaviour affects well-being and life satisfaction. The level of incomes has been considered as an important indicator (Glymour et al., 2014), due to it can causes financial difficulties (Kahn, 2018). Research on retirement should focus on helping citizens for the

*Corresponding author. E-mail: therrador@cee.uned.es

Copyright (c) 2020 The Author(s). Published by Vilnius Gediminas Technical University

This is an Open Access article distributed under the terms of the Creative Commons Attribution License (http://creativecommons. org/licenses/by/4.0/), which permits unrestricted use, distribution, and reproduction in any medium, provided the original author and source are credited. 
financial decision-making (Swift et al., 2019), as well as the maintenance of a good life quality level (Vidová \& Sika, 2020). Retirement is considered as a life-long decision-making process, with adjustments related to the retirement decision (Wang \& Wanberg, 2017), being the expectations of retirees before retirement a good estimator of the subsequent adjustments made (Yeung, 2013), by a dynamic and over time process (Chan et al., 2020). However, personal retirement planning is questioned due to people's limitations (Nam \& Loibl, 2020). That is why a large part of research has been focused on the saving behaviour and the influence of the education (Tamborini \& Kim, 2019) and financial literacy (Hauff et al., 2020). The present work applies a complete model to measure behavioural factors for retirement, and which integrates a set of predictors framed in social, psychological and financial factors (Gutierrez \& Hershey, 2014; Hershey et al., 1998, 2007, 2010, 2013; Hershey \& Mowen, 2000). Considering the prior literature, the objective of this work is to evaluate the joint influence of the three dimensions of Hershey et al. (2013) - capacity, disposition and opportunity, through a structural equation model (SEM) aimed at analysing what variables of personal financial planning in Spain could be determining personal financial management, and its relationship with resources available for retirement. According to the knowledge-based economy approach (Barkhordari et al., 2019; Heikka \& Carayannis, 2019), the predictive capacity of the proposed model could facilitate retirement personal planning, allowing to individuals the consideration of adjustments (capability overestimations, task procrastinations, retirement age, etc). The improvement could be obtained by promoting the management of complementary resources to the funds received from the public pension system, by helping individuals to have more complete information on their own retirement intentions and financial management capability. Thus, the structure for this article includes an introduction to the problem of retirement personal financial planning, the conceptual framework and literature, the model and method for the analysis, the results, the discussion, and the conclusions.

\section{Contextual framework and literature}

The analysis framework is based on financial behaviour for retirement, and it is organized around the importance of personal finance management within a complete model.

\subsection{Personal finance management for retirement by a complete model}

Welfare in the old age is linked to financial resources and health (Purnell et al., 2016; Ruberton et al., 2016; Weckroth et al., 2017), but incomes level (Amorim \& França, 2020) or age (Petkoska \& Earl, 2009) are not the unique predictors of the quality of planning and saving for retirement. The main difficulty for people is the early financial planning of the monetary resources for their future, because it requires foreseeing future needs when they are still nonexisting, implying a deferral of rewards (Hershfield et al., 2011). This financial behaviour for retirement planning involves the use of economic notions (Sherraden et al., 2011), that finally supposes to personal financial capacity, which must be understood as the implementation of financial knowledge. In addition, emotional factors could affect financial goals and retirement savings (Garmendia et al., 2019; Osborne, 2016). 
The model of Hershey et al. (2013) considers as reference the conceptual framework of working performance proposed by Blumberg and Pringle (1982), in order to analyse the antecedents of the behaviours of financial planning and saving for retirement, within effective financial planning for retirement. It allows to evaluate the financial resources for retirement by measuring self-perceptions that people have about to their own knowledge and intentions. Traditionally, the financial planning for retirement had been empirically studied mainly from the scope of the economy, despite that the saving decision processes do not depend only on economic factors, by involving personal behaviour, skills, and, cultural and environmental factors. The proposed model is an inclusive model, because it includes different aspects to explain the financial planning for retirement (FPR), not taking into consideration only economic factors (Hersey et al., 2007, 2013), and it simultaneously considers variables in three dimensions. Likewise, it is a procedural model because the temporal dimension is included, by analysing age and its interaction with the other facets of the model. This model proposes that the quality of planning and saving behaviour can be determined by three primary dimensions: (1) Capacity, (2) Willingness, and (3) Opportunity.

What is the Capacity in the FPR model of Hersey et al.? Capacity refers to the cognitive factors and skills necessary to plan and save for retirement for each person, such as knowledge, skills, fluid and crystallized intelligence, and psychological biases. These factors have been identified as key factors in financial planning for saving (Resende \& Zeidan, 2015). Thus, this first dimension groups the cognitive characteristics, abilities and skills that promote more effective financial management practices, based on Financial Literacy as the most powerful predictor of this (Hershey et al., 1998). Investment decisions for retirement and saving behaviour are considered in the model (Jacobs-Lawson \& Hershey, 2005), as well as trends to plan for retirement (Hershey et al., 2007). Due to effect of financial advice can have on financial decision-making, the search for specific financial information is also considered (Kimball \& Shumway, 2010).

What is the Willingness in the FPR model of Hersey et al.? Willingness consists of the motivational variables that drive planning activities and saving. Therefore, this dimension includes the motivational forces and the attitudinal and emotional factors that determine the probability that an individual will begin to plan and maintain activity over time (clarity and nature of financial goals, retirement-related fear and anxiety, perceived social norms, and self-image could be linked to the tendency to plan and save). Attitudinal and affective aspects drive people to save for retirement according to their goals (Hershey et al, 2007; Topa \& Herrador-Alcaide, 2016), because these aspects impact on financial behaviour (Hershey \& Mowen, 2000; Neukam \& Hershey, 2003). Also, it has been found that goal specification is a predictor of saving activities (Petkoska \& Earl, 2009), and hence the link between goals and attitudes. Attitudes towards one's financial situation in retirement, as well as more global beliefs concerning retirement in general are another predictor analysed in the literature and considered in this study (Van Dalen \& Henkens, 2005; Topa et al., 2009). Regarding Financial management behaviour, it has been confirmed that financial risk tolerance is positively associated to saving programs (Joo \& Grable, 2005).

What is the Opportunity in the FPR model of Hersey et al.? Opportunity recognizes the existence of certain external influences, including environmental enablers and constraints 
that affect effective financial allocation. Among others, the availability of savings programs for voluntary retirement, tax incentives for savings and financial advisers in the immediate environment would be associated with the tendency to plan and save. This dimension groups external influences that favours or restricts Financial Management Practices. In this sense, financial counselling is considered as a major influence in the financial planning of investments that reflect personal saving for retirement (Bodie, 2003) directly or by increasing the relevant information to manage (Goldstein et al., 2008).

Thus, by considering this model, FPR is a continuous process that develops throughout life and reaches its culmination in adulthood. It is precisely this continuous accumulation of knowledge, skills and practices that makes up a cumulative learning experience that is developed innately by individuals, who do not even perceive it. The fact that it is a continuous process would lead to expecting a stable pattern of strengthening the capacity, the willingness and the opportunities to save for retirement.

\subsection{The research approach of Hershey et al. (2013) in the Spanish economic context}

The influences caused by the evolution and reform of the pension system in many countries of European Union (EU) raised public awareness about the problem of the sustainability of the system. The continuity in the pattern of consolidation of the capacity, the willingness and the opportunities in the FPR of citizenship is not questioned when the pension systems is mainly based on the personal saving capacity, that is usual in liberal economies, where each individual bears their retirement. In the highly liberal economies, this pattern of behaviourcontinuous learning for saving is applied by citizens in all economic aspects of their lives, and practically, from their earliest childhood they unconsciously learn the importance of adequate financial management. On the contrary, individuals in economies with a wide social protection system have usually problems to manage this behaviour-continuous learning to relevant events of their lives associated with important payments. Even considering the differences existing in the pension systems of the EU, the states guarantee some system of social protection, so in the most guaranteeing countries there is no historical tradition of financial planning. In this sense and in order to achieve financial citizenship, the EU has been developing different policies to make citizens aware of the importance of financial literacy a financial planning. Financial literacy and, consequently, financial education (programs to improve financial literacy), are key factors in managing of personal finances and saving for the well-being in retirement time. These factors have been directly linked to the improvement of the financial qualification of citizens. The promotion of financial literacy through financial education has prompted several initiatives of the EU. The EU has reflected thus the need to improve the level of information for investors and consumers of financial services. Several actions, such as informative campaign and the sponsorships of financial training programs, together another initiatives, such as the National Securities Market Commission and the Bank of Spain, were focused to facilitate the financial citizenship in Spain (HerradorAlcaide \& Rios-Sastre, 2017). Also, the Human Development Index (HDI) for Spain, that is positioned in the highest range (0.8-1.0 points) (United Nations, 2019), shows a long- 
life expectancy and so, this drives to the need of implementing complementary savings for the sustainability of well-being in retirement. Seeing the awareness policies of EU and the Spanish HDI, Spanish society would be a favourable environment for retirement financial planning, nevertheless, there are still some obstacles to overcome. The policies aimed at the unsustainable growth of public spending, are far from the real economic situation of the countries and their economical sustainability (Avram et al., 2020). This policy is not justified salvo in specific times of grave social needs, and it has not promoted the citizen awareness regarding well-being sustainability in retirement and its relationship with savings.

All the previous arguments allow us to highlight the importance of this research, which focused on measuring the applicability of a complete model that has not yet been endorsed in socially guaranteeing economies, that is in Spain. The fact that there is not a historical tradition of retirement planning outside of the social guarantees offered by the State, further increases the social problem of the sustainability of pensions, because not only are there no complementary private savings for retirement, but there is also no social awareness of the need to save for this purpose. Added to this lack of awareness is the lack of economic and the difficult for decision-making capacity of citizenship, which are sometimes not mitigated by state policies. Thus, the present work based on Hersey's model to analyse financial planning process for retirement but in a context with a brief historical tradition in financial planning for retirement. The findings of the proposed model will suppose being able to contribute a self-knowledge proposal on personal retirement intentions. The practical application of this model would allow citizens to be made aware of the necessity to save for the retirement time. This could contribute to the sustainability of the welfare in Spain and in other economies with similar pension systems, by ensuring personal well-being in old age through the provision of complementary resources. Active public policies for training in financial planning for retirement could benefit from the use our model, which would allow knowing the starting position, both in terms of intention towards retirement, and in terms of ability to manage finances. Likewise, this model can be transmitted to different social agents, such as companies, teacher or other public agents, in order to allow a greater and better knowledge of the intentions towards the retirement in groups at risk of exclusion.

\section{Model and method}

The used model considers not only economic factors, but also some factors that differentiate the quality of Individuals' efforts in retirement-related financial planning. This quality factors are linked to the lifestyle of each person and the own way in which they manage their decision-making process for retirement. The model meassures the final resources by using as main predictor people's management practices for retirement in Spain (see Figure 1).

Due to the model is focused towards attitudinal factors, the Financial Management Practices was analyses by using of a set questions about recommended financial management practices and the possible obstacles to using those practices, which are effective usual tools to measure and hypothesize about how people manage and perceive their financial management (Davis \& Weber, 1990). The effect of financial management practices on Financial Resources (savings) (Sousa et al., 2019) supports the consideration of Financial Management Practices 


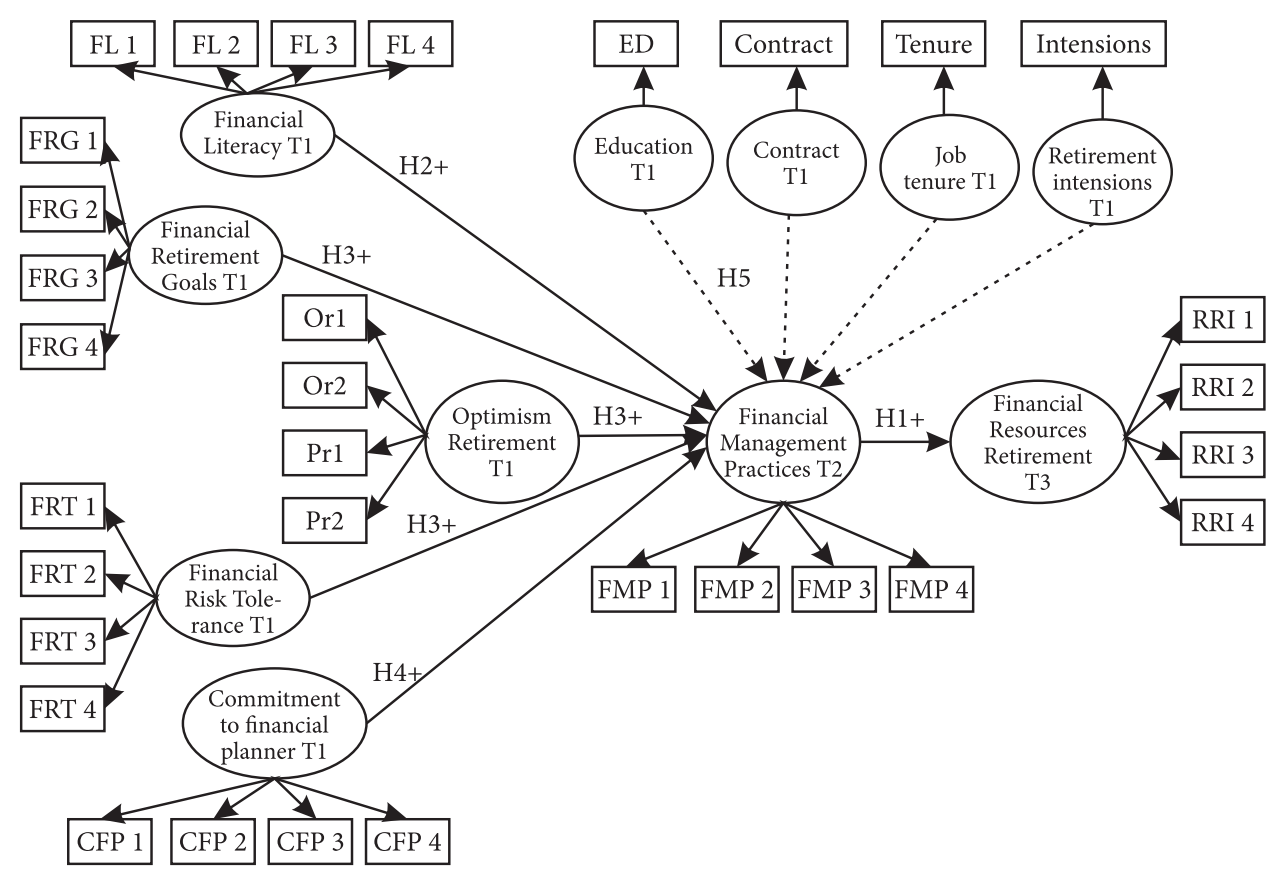

Figure 1. Hypothesized model (source: own developed by Smart-PLS)

as the key variable to determine the personal financial resources, as it is considered in the hypothesis No. $1\left(\mathrm{H}_{1}\right)$.

The hypotheses No. 2 and $3\left(\mathrm{H}_{2}\right.$ and $\left.\mathrm{H}_{3}\right)$ involve variables that can affect financial management practices (Hershey et al., 2013). Regarding $\mathrm{H}_{2}$, Financial Literacy has usually been identified as the key variable to explain the Financial Management Practices (Lusardi \& Mitchell, 2014), and finally on the retirement due to poor debt management (Lusardi et al., 2020). Financial Literacy is typically considered as an input to explain variation in financial outcomes (Huston, 2010). From a social constructionist perspective (Danes \& Haberman, 2007), financial literacy is not considered as a static knowledge, rather it is considered for its relationship with financial concern (Taft et al., 2013) and the attitudinal factors linked to financial capability (Loke et al., 2015). The willingness of planning and saving is analysis in the $\mathrm{H}_{3}$, considering the joint effect of Financial Retirement Goals (Stawski et al., 2007), Optimism about Retirement (Joo \& Grable, 2005) and Financial Risk Tolerance (Cho \& Lee, 2006), as it is considered in the framework applied to the model of Hershey et al. $(2007,2013)$. The effect of retirement goals on the financial practices has been identified as a complementary variable together attitude towards financial risk and the optimism (JacobsLawson, \& Hershey, 2005; Petkoska \& Earl, 2009; Wang \& Shi, 2014).

By the hypothesis No. $4\left(\mathrm{H}_{4}\right)$, the commitment to a financial planner is introduced in the model as the last relevant variable on Financial Management Practices according a previous works (Davis \& Weber, 1990), because the mediation of a financial planner is normally used to overcome the obstacles linked to the complex decisions-making, such as financial decisions. Finally, the hypothesis No. $5\left(\mathrm{H}_{5}\right)$ introduces the control variables of Financial 
Management Practices according to Zaniboni et al. (2010) - Education, type of employment, job tenure, length of their job, by considering aging's role (Zaniboni, 2015) in the financial decision-making towards retirement according to the framework. Variables linked to the people's job environment affect to design retirement strategies and they usually have effect on previous financial practices in retirement time (Claes \& Van Loo, 2011; Davies et al., 2017). Other control variable on financial practices is the large levels of education associated to better financial practices for retirement saving behaviour (Koposko et al., 2016).

The following five hypotheses are tested in this model (see Figure 2):

- Hypothesis about the model capacity to predict the financial resources at retirement time:

- Hypothesis $1\left(H_{1}\right)$ : Financial Management Practices (T2) will have a positive influence on Financial Resources for retirement (T3).

- Hypotheses about variables that can affect financial management practices through quality of planning and saving behaviour considering the three primary dimensions of Hershey's model (capacity to perform such behaviour, willingness and opportunities): - Hypothesis $2\left(\mathrm{H}_{2}\right)$ : The Financial Literacy (T1) will have a positive influence on Financial Management Practices (T2).

- Hypothesis $3\left(\mathrm{H}_{3}\right)$ : The willingness of planning and saving, which is measured (T1) by Financial Retirement Goals, Optimism about Retirement; and Financial Risk Tolerance) will have a positive influence on Financial Management Practices (T2).

- Hypothesis $4\left(\mathrm{H}_{4}\right)$ : The commitment to consult with a financial planner (T1) will have a positive influence on Financial Management Practices (T2).

- Hypothesis about effect of individual attributes:

- Hypothesis $5\left(\mathrm{H}_{5}\right)$ : Individual attributes, educational level, type of employment contract, full retirement intentions and job tenure (T1) will have no significant influence on Financial Management Practices (T2).

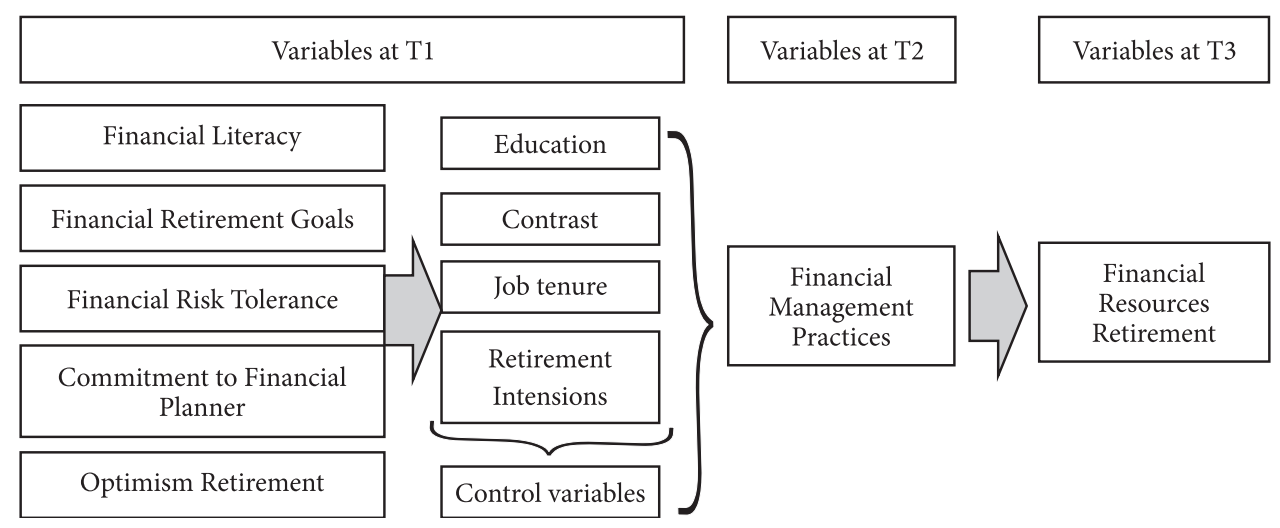

Figure 2. Variables of the model

\subsection{Sample, procedure and variables}

The Sample of the study includes Spanish workers $(\mathrm{N}=452)$ who were in transition to retirement. They were working at T1, T2, and they were retired at T3. To collect the data, twenty 
firms were contacted, and eleven organizations finally took part. At T1, 956 employees aged 60 or more received the questionnaire, a letter explaining the purpose of the study and the data collection procedure, as well as an envelope to return the survey. 783 employees completed questionnaire (response rate of $82 \%$ ). Approximately three months later, a second questionnaire was sent (response rate of 79\%). One year later, the third questionnaire was sent and completed by 457 retirees (response rate $74 \%$ ). The final depurated sample consisted of 452 participants. In the sample the $48.5 \%$ were men with the mean age in 62.5 years at T1 $(\mathrm{SD}=11.9)$. The $66.4 \%$ of workers were married and their mean job tenure was 17.4 years $(\mathrm{SD}=12.9)$ at Time 1 . The $77.2 \%$ corresponds to full time workers. The $50.9 \%$ of the sample held a university degree. Table 1 shows how variables were conformed.

Table 1. Variables

\begin{tabular}{|c|c|c|}
\hline \multicolumn{3}{|c|}{ VARIABLES (T1) } \\
\hline Control variables & $\begin{array}{l}\text { Education, contract and job tenure were } \\
\text { measured by the maximum level of formal } \\
\text { education, full time or part time contract, and the } \\
\text { length of their job. }\end{array}$ & Zaniboni et al. (2010) \\
\hline Financial Literacy & $\begin{array}{l}\text { This variable was assessed using the Financial } \\
\text { Knowledge Scale. }\end{array}$ & $\begin{array}{l}\text { Danes and Haberman } \\
(2007)\end{array}$ \\
\hline $\begin{array}{l}\text { Financial } \\
\text { Retirement Goals }\end{array}$ & $\begin{array}{l}\text { This variable was assessed with the "Retirement } \\
\text { Goals Clarity Scale". }\end{array}$ & Stawski et al. (2007) \\
\hline $\begin{array}{l}\text { Optimism about } \\
\text { Retirement }\end{array}$ & $\begin{array}{l}\text { Measurement by using both the Optimistic and } \\
\text { the Pessimistic Retirement Attitude Scales }\end{array}$ & Joo and Grable (2005) \\
\hline $\begin{array}{l}\text { Financial Risk } \\
\text { Tolerance }\end{array}$ & It was assessed with the Risk-Propensity Scale. & Cho and Lee (2006) \\
\hline $\begin{array}{l}\text { Commitment to a } \\
\text { financial planner }\end{array}$ & $\begin{array}{l}\text { It was assessed with the Commitment to } \\
\text { "Financial Planner scale". }\end{array}$ & Sharpe et al. (2007) \\
\hline \multicolumn{3}{|c|}{ VARIABLES (T2) } \\
\hline $\begin{array}{l}\text { Financial } \\
\text { Management } \\
\text { Practices }\end{array}$ & $\begin{array}{l}\text { Budgeting, record keeping, budget record } \\
\text { comparisons and balance sheet preparation were } \\
\text { the practices included in this measure. }\end{array}$ & Davis and Weber (1990) \\
\hline \multicolumn{3}{|c|}{ VARIABLES (T3) } \\
\hline $\begin{array}{l}\text { Financial } \\
\text { Resources for } \\
\text { Retirement }\end{array}$ & $\begin{array}{l}\text { Four items were used from the Financial } \\
\text { Resources subscale of the Retirement Resources } \\
\text { Inventory. }\end{array}$ & Leung and Earl (2012) \\
\hline
\end{tabular}

\subsection{Model specification and statistical analysis}

The present work proposes a model by SEM (see Figure 1). It was used Smart PLS 3.0, because no assumptions about data distributions (Ringle et al., 2015). Due to the primary aims of applying SEM are to develop theory or explain the variance of the constructs (Hair et al., 2016), SEM by PLS is an suitable method based on variance, that is considered as adequate method to estimate the constructs of the latent variables in each paths (Richter et al., 2016). To ensure the statistical significance of the SEM, a bootstrapping of 500 samples was carried out, each with 452 cases (the critical value taken by $\mathrm{t}=1.96$, stands at a $\mathrm{p}$-value $<0.05$ ). The observed item scores were used as indicators for latent endogenous variables. 


\section{Results}

The results of the analysis are shown in the following sections.

\subsection{Correlations}

Table 2 reports the means, standard deviations and correlations of the variables.

Table 2. Correlation matrix

\begin{tabular}{|c|c|c|c|c|c|c|c|c|c|}
\hline VARIABLES & 1 & 2 & 3 & 4 & 5 & 6 & 7 & 8 & 9 \\
\hline \multicolumn{10}{|l|}{ Control } \\
\hline \multicolumn{10}{|l|}{ 1. Job Tenure (T1) } \\
\hline $\begin{array}{l}\text { 2. Total Retirement } \\
\text { Intentions (T1) }\end{array}$ & $0.10^{*}$ & & & & & & & & \\
\hline \multicolumn{10}{|l|}{ Predictors } \\
\hline 3. Financial Literacy (T1) & $0.14^{\star}$ & 0.00 & 0.71 & & & & & & \\
\hline $\begin{array}{l}\text { 4. Financial Retirement } \\
\text { Goals (T1) }\end{array}$ & $0.19^{\star *}$ & 0.00 & $0.17^{\star *}$ & 0.79 & & & & & \\
\hline $\begin{array}{l}\text { 5. Optimism about } \\
\text { Retirement (T1) }\end{array}$ & $0.12^{\star}$ & $0.10^{\star}$ & $0.20^{\star *}$ & $0.21^{\star *}$ & 0.95 & & & & \\
\hline $\begin{array}{l}\text { 6. Financial Risk } \\
\text { Tolerance (T1) }\end{array}$ & 0.00 & -0.03 & 0.09 & 0.02 & 0.06 & 0.84 & & & \\
\hline $\begin{array}{l}\text { 7. Commitment to } \\
\text { Financial Planner (T1) }\end{array}$ & $0.40^{* *}$ & -0.00 & $0.35^{\star *}$ & $0.20^{\star *}$ & $0.13^{\star *}$ & 0.08 & 0.69 & & \\
\hline $\begin{array}{l}\text { 8. Financial Management } \\
\text { Practices (T2) }\end{array}$ & $0.37^{\star *}$ & 0.02 & $0.31^{* *}$ & $0.30^{* *}$ & $0.30^{* *}$ & 0.08 & $0.37^{* *}$ & 0.78 & \\
\hline \multicolumn{10}{|l|}{ Outcome } \\
\hline $\begin{array}{l}\text { 9. Financial Resources for } \\
\text { Retirement (T3) }\end{array}$ & $0.37^{\star *}$ & -0.08 & $0.33^{\star *}$ & $0.22^{\star *}$ & $0.27^{\star *}$ & $0.16^{\star *}$ & $0.40^{* *}$ & $0.62^{\star *}$ & 0.79 \\
\hline
\end{tabular}

Note: $N=452\left({ }^{\star} p<0.05 ;{ }^{* *} p<0.01\right)$.

According to Table 2, the associations with a $\mathrm{p}<0.01$ are highlighted below:

- Financial Goals for Retirement (variable 4) correlates with Financial Literacy (variable 3) and Job Tenure (variable 1).

- Optimism for retirement (variable 5) has a strong association with Financial Literacy (variable 3) and with Financial Goals for Retirement (variable 4).

- Commitment to a Personal Planner (variable 7) correlates with Job Tenure (variable 1), with Financial Literacy (variable 3), with Financial Goals for Retirement (variable 4) and with Optimism for retirement (variable 5).

- Financial management practices (T2) (variable 8) are correlated with all variables, except for variables 2 (Total Retirement Intentions) and 6 (Financial Risk Tolerance).

- Financial resources for retirement (T3) (variable 9), which is the final objective of the model, is correlated with all the variables in the model. 


\subsection{Measurement model}

The reliability indicator was assessed by the statistical significance of the standardized factorial loadings. In the rule of thumb for the evaluation of measurement models, indicator loadings should be higher than 0.70 , and outer loadings between 0.40 and 0.60 should be removed only if this implies a composite reliability increase (Hair et al., 2016). Composite reliability is the preferred alternative to Cronbach's alpha as a measure of internal consistency, and the score obtained should be higher than 0.70 . Table 3 displays the results of the outer model, showing that the constructs of financial literacy (T1), financial retirement goals (T1), and optimism about retirement (T1), financial risk tolerance (T1), commitment to a financial planner (T1), financial management practices (T2) and financial resources for retirement (T3) exceed the minimum requirements.

\subsection{Convergent and discriminant validity}

Convergent validity represents the common variance between the indicators and their construct, and so, the criterion of average variance extracted (AVE) should be higher than 0.50 (Hair et al., 2016). Fornell and Larcker (1981) stated that if AVE is less than 0.50 but composite reliability is higher than 0.60 , the convergent validity of the construct is still adequate. As shown in Table 3, the AVE for each construct was satisfactory, except for commitment to a financial planner, which was lower than 0.50 , but the composite reliability values were higher than 0.85 . To assess the discriminant validity between constructs, the square root of AVE for each construct should be greater than its highest correlation with any other construct (Fornell \& Larcker, 1981).

Table 3. Measurement model: Reliability and convergent validity

\begin{tabular}{|c|c|c|c|}
\hline Latent variable & Lambda & Composite Reliability & AVE \\
\hline \multirow{5}{*}{ Financial Literacy (T1) } & 0.78 & \multirow{5}{*}{0.83} & \multirow{5}{*}{0.51} \\
\hline & 0.68 & & \\
\hline & 0.50 & & \\
\hline & 0.76 & & \\
\hline & 0.79 & & \\
\hline \multirow{4}{*}{ Financial Retirement Goals (T1) } & 0.68 & \multirow{4}{*}{0.86} & \multirow{4}{*}{0.62} \\
\hline & 0.86 & & \\
\hline & 0.82 & & \\
\hline & 0.78 & & \\
\hline \multirow{4}{*}{ Optimism about Retirement (T1) } & 0.93 & \multirow{4}{*}{0.97} & \multirow{4}{*}{0.91} \\
\hline & 0.95 & & \\
\hline & 0.96 & & \\
\hline & 0.96 & & \\
\hline \multirow{4}{*}{ Financial Risk Tolerance (T1) } & 0.75 & \multirow{4}{*}{0.91} & \multirow{4}{*}{0.71} \\
\hline & 0.90 & & \\
\hline & 0.88 & & \\
\hline & 0.84 & & \\
\hline
\end{tabular}


End of Table 3

\begin{tabular}{|c|c|c|c|}
\hline Latent variable & Lambda & Composite Reliability & AVE \\
\hline \multirow{4}{*}{$\begin{array}{l}\text { Commitment to financial planner } \\
\text { (T1) }\end{array}$} & 0.56 & \multirow{4}{*}{0.78} & \multirow{4}{*}{0.48} \\
\hline & 0.67 & & \\
\hline & 0.74 & & \\
\hline & 0.78 & & \\
\hline \multirow{4}{*}{$\begin{array}{l}\text { Financial Management Practices } \\
\text { (T2) }\end{array}$} & 0.80 & \multirow{4}{*}{0.85} & \multirow{4}{*}{0.60} \\
\hline & 0.77 & & \\
\hline & 0.74 & & \\
\hline & 0.78 & & \\
\hline \multirow{4}{*}{$\begin{array}{l}\text { Financial Resources for Retirement } \\
\text { (T3) }\end{array}$} & 0.70 & \multirow{4}{*}{0.87} & \multirow{4}{*}{0.63} \\
\hline & 0.92 & & \\
\hline & 0.92 & & \\
\hline & 0.61 & & \\
\hline
\end{tabular}

The sensitivity of Fornell and Larcker's (1981) criteria to establish the constructs' discriminant validity has been tested (HTMT - Heterotrait Method, Monotrait Method). According to Gold et al. (2001), hoe all values in the matrix were lower than 0.90, the discriminant validity among the latent constructs was ensured (see Table 4).

Table 4. Measurement model: Discriminant Validity according to HTMT criteria

\begin{tabular}{|c|c|c|c|c|c|c|c|c|c|c|}
\hline VARIABLES & 1 & 2 & 3 & 4 & 5 & 6 & 7 & 8 & 9 & 10 \\
\hline \multicolumn{11}{|l|}{ 1. Financial Literacy (T1) } \\
\hline $\begin{array}{l}\text { 2. Financial Retirement } \\
\text { Goals (T1) }\end{array}$ & 0.205 & & & & & & & & & \\
\hline $\begin{array}{l}\text { 3. Optimism to } \\
\text { Retirement (T1) }\end{array}$ & 0.198 & 0.173 & & & & & & & & \\
\hline $\begin{array}{l}\text { 4. Financial Resources } \\
\text { for Retirement (T3) }\end{array}$ & 0.471 & 0.279 & 0.290 & & & & & & & \\
\hline $\begin{array}{l}\text { 5. Financial Risk } \\
\text { Tolerance (T1) }\end{array}$ & 0.183 & 0.069 & 0.152 & 0.211 & & & & & & \\
\hline 6. Type of Contract & 0.086 & 0.090 & 0.036 & 0.199 & 0.041 & & & & & \\
\hline 7. Education & 0.196 & 0.082 & 0.156 & 0.136 & 0.067 & 0.015 & & & & \\
\hline $\begin{array}{l}\text { 8. Commitment to Fi- } \\
\text { nancial planning (T1) }\end{array}$ & 0.572 & 0.262 & 0.071 & 0.699 & 0.200 & 0.226 & 0.195 & & & \\
\hline $\begin{array}{l}\text { 9. Financial Management } \\
\text { Practices (T2) }\end{array}$ & 0.469 & 0.379 & 0.336 & 0.911 & 0.139 & 0.146 & 0.083 & 0.595 & & \\
\hline $\begin{array}{l}\text { 10. Total Retirement } \\
\text { Decisions (T1) }\end{array}$ & 0.047 & 0.049 & 0.040 & 0.098 & 0.048 & 0.100 & 0.151 & 0.053 & 0.037 & \\
\hline 11. Job tenure (T1) & 0.155 & 0.220 & 0.067 & 0.415 & 0.048 & 0.221 & 0.108 & 0.544 & 0.419 & 0.104 \\
\hline
\end{tabular}




\subsection{Results of the structural model}

The inner model involves an evaluation of the pathways between latent constructs, using regression in which the regressors can be interpreted as standardized beta coefficients. The confidence intervals of the path coefficients are based on a bootstrapping process involving 500 samples, which allows the generalization of results and the computation of Student's $t$ for each hypothesis. The recommended criterion to assess the structural model is the coefficient of determination $\left(R^{2}\right)$, which should be higher than 0.10 . According to the results, the $t$-statistics were higher than 1.96 for all the variables in the model. Thus, the $\mathrm{H}_{1}, \mathrm{H}_{2}$ and $\mathrm{H}_{4}$ were fully supported by the model, but $\mathrm{H}_{3}$ and $\mathrm{H}_{5}$ were partially supported (see Table 5). The predictive capacity of the model was satisfactory because all $R^{2}$ s were $>0.10$. To determine the predictive relevance of endogenous variable (how each path can predict the originally observed values), the Q2-value takes low and middle values for financial management practices $(\mathrm{T} 2)(\mathrm{Q} 2=.21)$, but it takes a higher value for retirement financial resources (T3) $(\mathrm{Q} 2=.33)$ (see Figure 3).

\subsection{Fit of the model}

The standardized root means square residual (SRMR) allows evaluating the magnitude of the discrepancies between the observed and expected correlations, and it can be interpreted as

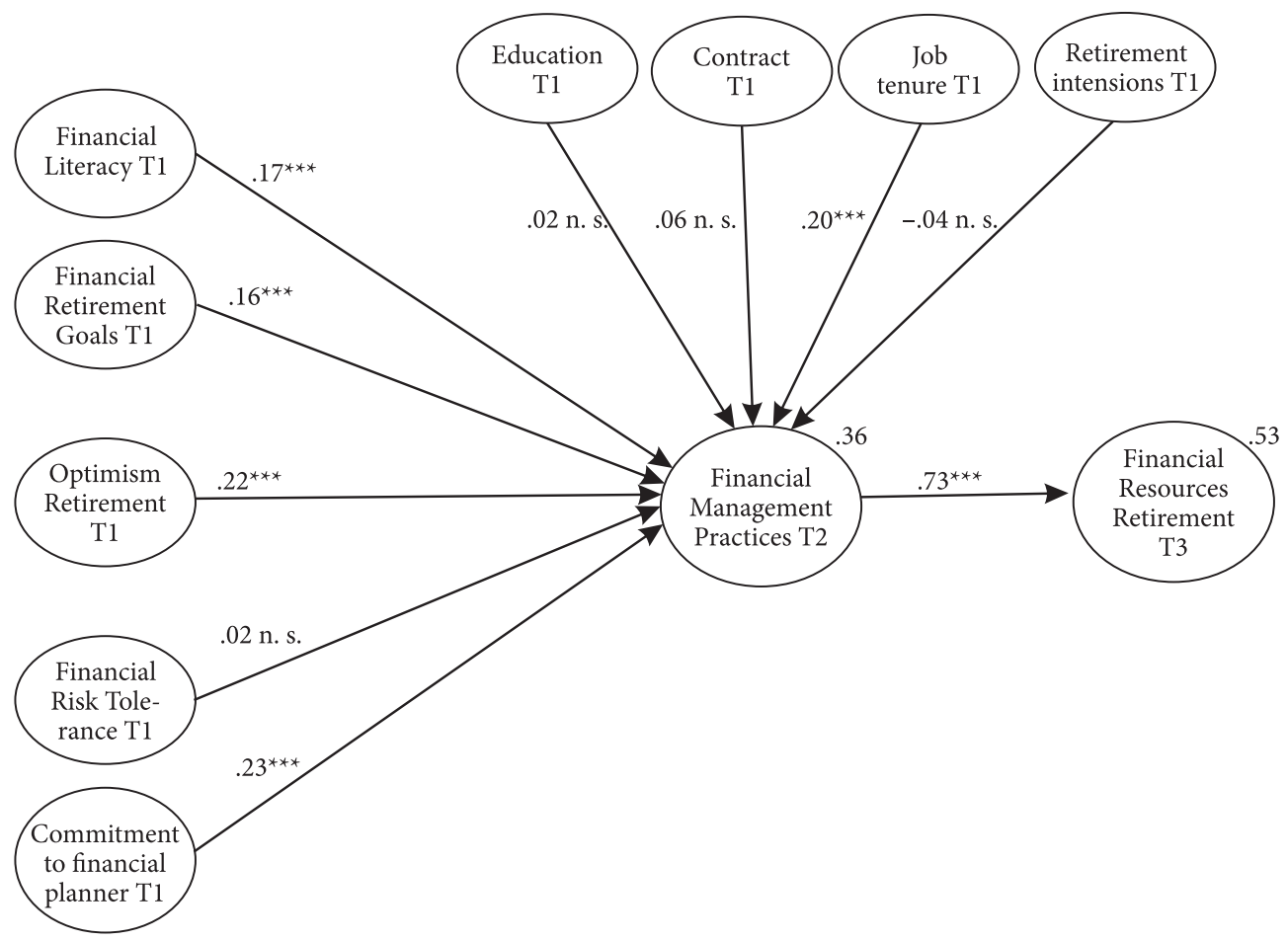

Note: ${ }^{* *} \mathrm{p}<.001$. n.s.: non-significant.

Figure 3. Resulting model 
an absolute measure of the fit of the model. Values lower than 0.08 are considered a good fit (Hu \& Bentler, 1999). In this work, the SRMR value for the saturated model was 0.062 , and for the estimated model it was 0.067 . Thus, the model reaches an acceptable fit. Table 5 summarises the results of the empirical analysis by SEM.

Table 5. Summary of findings according to hypotheses

\begin{tabular}{|c|l|l|l|}
\hline $\begin{array}{c}\text { Hypo- } \\
\text { theses }\end{array}$ & \multicolumn{1}{|c|}{ Findings } & $\begin{array}{c}\beta \text { and } t \text { for } \\
\text { positive influence }\end{array}$ & $\begin{array}{l}\text { Acceptation / } \\
\text { Rejection }\end{array}$ \\
\hline $\mathrm{H}_{1}$ & $\begin{array}{l}\text { Financial management practices (T2) significantly } \\
\text { influenced on Financial resources for retirement (T3). } \\
\text { The relationship was positive. }\end{array}$ & $\beta=.73, t=16.3$ & $\begin{array}{l}\text { Fully } \\
\text { supported }\end{array}$ \\
\hline $\mathrm{H}_{2}$ & $\begin{array}{l}\text { Financial literacy (T1) exerted a positive influence on } \\
\text { financial management practices (T2). }\end{array}$ & $\beta=.17, t=3.4$. & $\begin{array}{l}\text { Fully } \\
\text { supported }\end{array}$ \\
\hline $\mathrm{H}_{3}$ & $\begin{array}{l}\text { Optimism about retirement (T1) and Financial } \\
\text { retirement goals (T1) had significant influence on } \\
\text { Financial management practices (T2), both two. } \\
\text { Financial risk tolerance (T1) had no significant } \\
\text { influences. }\end{array}$ & $\begin{array}{l}\beta=.22, t=5.3 \\
\text { and } \\
\beta=.16, t=3.8, \\
\text { respectively }\end{array}$ & $\begin{array}{l}\text { Partially } \\
\text { supported }\end{array}$ \\
\hline $\mathrm{H}_{4}$ & $\begin{array}{l}\text { The path between Commitment to a financial } \\
\text { planner (T1) had a positive influence on financial } \\
\text { management practices (T2). }\end{array}$ & $\beta=.23, t=4.9$ & $\begin{array}{l}\text { Fully } \\
\text { supported }\end{array}$ \\
\hline $\mathrm{H}_{5}$ & $\begin{array}{l}\text { The relationship between Job tenure and Financial } \\
\text { management practices were statistically significant. } \\
\text { The paths from individual attributes (educational } \\
\text { level, type of employment contract, and full } \\
\text { retirement intentions, at T1) to financial management } \\
\text { practices (at T2), were statistically non-significant. }\end{array}$ & $\beta=.20, t=4.2$ & $\begin{array}{l}\text { Partially } \\
\text { supported }\end{array}$ \\
\hline $\begin{array}{l}\text { The integral model of Hershey et al. (2013) has predictive capacity to explain financial behaviours } \\
\text { oriented towards retirement in Spanish citizens. }\end{array}$ & $\begin{array}{l}\text { Effect of variables of T1 on Variable in T2 } \\
\text { Retirement) and opportunities (Commitment to Financial Planning) exert significant influence on } \\
\text { behaviours, predicting the 36\% of the variance of Financial Management Practices. }\end{array}$ \\
\hline
\end{tabular}

\section{Discussion}

The findings supported the hypotheses about the joint influence of the three dimensions of the model - capacity, willingness and opportunity - on financial management practices when workers are still active, and the effect of this one on the available financial resources when workers have already retired. The findings can be framed within the studies that shows the positive effect of planning on welfare in retirement (Barbosa et al., 2016). These results are important due to the strong relationship among financial welfare, health and life satisfaction (Purnell et al., 2016; Ruberton et al., 2016; Weckroth et al., 2017), because the loss of financial resources is a negative predictor of life satisfaction during retirement (Kendig et al., 2016). 
The findings highlight the predictive capacity of the model, in order to explain retirement financial behaviours in samples of Spanish workers. In this sense, capacity (Financial Literacy), willingness (only the Financial Goals and Optimism) and opportunities (Commitment to Financial Planning) all exert significant influence on behaviours. Thus, the joint effect of previous variables can predict $36 \%$ of the variance of financial management practices. The results of our work demonstrate that financial behaviour towards retirement is based not only on economic or educational factors, but also on emotional factors linked to personal ability to plan towards period that precedes death (Major et al., 2016) and attitudinal personal factors (Hoffmann \& Plotkina, 2020).

Regarding the variables in T1, it is noteworthy that the most important source of influences to determine financial management behaviour seems to be attitudes. Accordingly to prior findings (Kim et al., 2018; Topa et al., 2018), commitment to consulting evidenced a strong influence on financial management behaviour, that suggest that financial planners do help individuals achieve their retirement financial objectives by highlighting the importance of retirement planning, and they can improve the decision-making process (Engelmann et al., 2009; Kramer, 2012), and consequently individuals can get greater return on investments (Allie et al., 2016). Contrarily to the result of Marsden et al. (2011), financial advisory in the present study was not related to retirement savings.

Continuing with the variables at T1, and accordingly to prior works, the positive effect of personal goals for retirement on financial management behaviour is noted (Hershey \& Mowen, 2000; Hershey et al., 2007; Topa \& Herrador-Alcaide, 2016; Topa et al., 2018) or its effects on the retirement saving contributions (Stawski et al., 2007). Furthermore, Financial knowledge (T1) also shows a positive relevant effect on the financial management behaviour in the present study, that confirms individuals' financial knowledge is predictive of saving practices for retirement (Jacobs-Lawson \& Hershey, 2005) and, as a consequence, the positive effect on retirement planning (Bucher-Koenen \& Lusardi, 2011), because individuals who show more advance financial knowledge are those more ready for retirement planning (Lusardi \& Mitchell, 2009).

The findings of the present study show that financial literacy causes a positive effect on financial management practice, as in prior works (Crossan et al., 2011; Kalmi \& Ruuskanen, 2017). It has been shown that workers who completed an educational module related to financial literacy were more likely to start contributing to saving for retirement (Clark et al., 2017). Thus, our findings show that financial education is correlated with preparation for retirement, that implies complex financial decision-making and the possession of financial knowledge for retirement (Elinder et al., 2019). Recent works found that groups with a lack of financial training, such as people with lower educational levels, were the least likely to plan financially for retirement (Arrondel et al., 2013; Kopanidis et al., 2017), nevertheless education was not a significant variable for financial management practices in our findings. Furthermore, and contrary to the findings of Magendans et al. (2016), tolerance to financial risk did not have a significant relationship with the behaviour of financial management, but could be due to the type of the family nucleus that affects perceived risk (Addoum, 2017), a variable that has not been considered.

Finally, it is known that optimism towards retirement cause a positive effect on retirement planning (Karlsson \& Allwoo, 2016), and, also on retirement adjustment quality (Niu 
\& Gibson, 2020). The findings of the present study verified optimism is related to financial management practices and, subsequently, on financial resources, such as it was found in prior literature (Joo \& Grable, 2005; Topa \& Pra, 2018). A heightened appreciation of the future would enable people optimal decision-making ex post that others find too costly ex ante (Puri \& Robinson, 2007). Hence, the importance of self-knowledge of personal intentions for proper financial planning. The job tenure (Zaniboni et al., 2010) is considered as a control variable on financial planning, and it the present work it was the only control variable with positive effect on financial management practices.

As global conclusion, the findings of the present paper support that the model hypothesized can explain 53\% of the total variance of the available financial resources in retirement.

\section{Conclusions}

The most interesting findings of this study indicate that the application of a model that considers the capacity, willingness and opportunity for retirement planning, can be used to predict the financial resources available in retirement, from the perspective of selfknowledge of one's personal intentions for retirement. As second conclusion, the validity of the model to anticipate financial management practices towards upcoming retirement is verified, which would allow the self-knowledge of personal financial behaviour before retirement and, consequently, the improvement of personal financial behaviour towards retirement. The results show that it would be possible to apply a model based on selfevaluation for retirement planning, in order to implement a complementary financial planning to the public pension. This research can be extended to other countries and groups of individuals, in spite that a limitation to the comparation of the findings of this work could be the use of different measurements for the variables, that could offer different results for a similar model. In spite this limitation, that is usual in modelling, the findings would result in a global benefit for society, by offering a better financial management by using the self-knowledge. In this way, the conclusions of the present work would allow to nonexpertise people in finance self-check their real intensions for retirement, that allows to do a good prognostic on the future financial resources at time of retirement based on their personal goal for the retirement. This knowledge should permit to rectify certain personal attitudes, such as the need of to take financial advice or delay the time of retirement. Also, people could become aware about personal difficulties, such as financial non literacy. All the potentialities of a better self-knowledge about personal planning for retirement suppose a potential benefit for the joint of society. Considering the knowledge economy, the good working of this complete model for the prognostic of personal financial resources, suppose a great of real possibilities for personal knowledge applied to the financial planning for retirement. Accordingly, a greater self-knowledge could help policy makers in aspects such as economics, health or education through the improvement of the knowledge of retirement intentions and goals of individuals.

Consequently, a future extension for this research could be focused on the relationships between public policies of social expenditure in the country and the real amount of 
complementary retirement saving in the country, considering thus another near research field as the economic policy or behavioural sociology. Also, it would be interesting to consider as an attitudinal factor the citizens' awareness towards the social country expenditure, by measuring its effect on personal retirement goals, personal management practices and final retirement resources. This could show the need of adjustment of the model by the differentiation between protectionist economies and liberal economies, in order to find a degree of balance between contributions from the public pension system and a private system for the welfare in retirement time.

\section{Acknowledgements}

The authors are grateful to anonymous referees for their comments, which contributed greatly to this final version, as well as Dr. R. Martinkute-Kauliene. The authors also want to thank the Department of Social and Organizational Psychology (Faculty of Psychology-UNED) and the Department of Economics and Business Accounting (Faculty of Economics and BusinessUNED) for their support in promoting scientific research.

\section{Author contributions}

Authors contributed equally in the design and development of the paper.

\section{References}

Addoum, J. M. (2017). Household portfolio choice and retirement. Review of Economics and Statistics, 99(5), 870-883. https://doi.org/10.1162/REST_a_00643

Allie, J., West, D., \& Willows, G. (2016). The value of financial advice: An analysis of the investment performance of advised and non-advised individual investors. Investment Analysts Journal, 45(1), 63-74. https://doi.org/10.1080/10293523.2016.1201292

Amorim, S. M., \& França, L. H. D. F. P. (2020). Health, financial and social resources as mediators to the relationship between planning and satisfaction in retirement. Current Psychology. https://doi.org/10.1007/s12144-020-00836-8

Arrondel, L., Debbich, M., \& Savignac, F. (2013). Financial literacy and financial planning in France. Numeracy, 6(2), 8. https://doi.org/10.5038/1936-4660.6.2.8

Avram, A., Barna, F. M., Năchescu, M. L., Avram, C. D., \& Avram, R. L. (2020). Responsible governance and the sustainability of populist public policies. The implications of wage-led growth strategy in Romania. Sustainability, 12(7), 2975. https://doi.org/10.3390/su12072975

Barbosa, L. M., Monteiro, B., \& Murta, S. G. (2016). Retirement adjustment predictors - A systematic review. Work, Aging and Retirement, 2(2), 262-280. https://doi.org/10.1093/workar/waw008

Barkhordari, S., Fattahi, M., \& Azimi, N. A. (2019). The impact of knowledge-based economy on growth performance: Evidence from MENA countries. Journal of the Knowledge Economy, 10(3), 1168-1182. https://doi.org/10.1007/s13132-018-0522-4

Blumberg, M., \& Pringle, C. D. (1982). The missing opportunity in organizational research: Some implications for a theory of work performance. Academy of Management Review, 7(4), 560-569. https://doi.org/10.5465/amr.1982.4285240 
Bodie, Z. (2003). An analysis of investment advice to retirement plan participants. In O. Mitchell \& K. Smetters (Eds.), The pension challenge: Risk transfers and retirement income security (pp. 19-32). Oxford University Press. https://doi.org/10.1093/0199266913.003.0002

Bucher-Koenen, T., \& Lusardi, A. (2011). Financial literacy and retirement planning in Germany. Journal of Pension Economics \& Finance, 10(4), 565-584. https://doi.org/10.1017/S1474747211000485

Chan, M. C., Chung, E. K., \& Yeung, D. Y. (2020). Attitudes toward retirement drive the effects of retirement preparation on psychological and physical well-being of Hong Kong Chinese retirees over time. The International Journal of Aging and Human Development, 0091415020926843. https://doi.org/10.1177/0091415020926843

Cho, J., \& Lee, J. (2006). An integrated model of risk and risk-reducing strategies. Journal of Business Research, 59(1), 112-120. https://doi.org/10.1016/j.jbusres.2005.03.006

Claes, R., \& Van Loo, K. (2011). Relationships of proactive behaviour with job-related affective wellbeing and anticipated retirement age: an exploration among older employees in Belgium. European Journal of Ageing, 8(4), 233-241. https://doi.org/10.1007/s10433-011-0203-7

Clark, R., Lusardi, A., \& Mitchell, O. S. (2017). Employee financial literacy and retirement plan behavior: a case study. Economic Inquiry, 55(1), 248-259. https://doi.org/10.1111/ecin.12389

Crossan, D., Feslier, D., \& Hurnard, R. (2011). Financial literacy and retirement planning in New Zealand. Journal of Pension Economics \& Finance, 10(4), 619-635. https://doi.org/10.1017/S1474747211000515

Danes, S. M., \& Haberman, H. (2007). Teen financial knowledge, self-efficacy, and behavior: A gendered view. Journal of Financial Counseling and Planning, 18(2), 48-60.

Davies, E. M., Van der Heijden, B. I., \& Flynn, M. (2017). Job satisfaction, retirement attitude and intended retirement age: a conditional process analysis across workers' level of household income. Frontiers in Psychology, 8, 891. https://doi.org/10.3389/fpsyg.2017.00891

Davis, E. P., \& Weber, J. A. (1990). Patterns and obstacles to financial management. Financial Counseling and Planning, 1, 41-51.

Elinder, M., Hagen, J., Nordin, M., \& Säve-Söderbergh, J. (2019). Pension knowledge, financial literacy, and retirement planning. Semantic Scholar. Retrieved October 01, 2020, from https://www.semanticscholar.org/author/Johannes-Hagen/35780057

Engelmann, J. B., Capra, C. M., Noussair, C., \& Berns, G. S. (2009). Expert financial advice neurobiologically "offloads" financial decision-making under risk. PLoS One, 4(3), e4957.

https://doi.org/10.1371/journal.pone.0004957

Fornell, C., \& Larcker, D. F. (1981). Evaluating structural equation models with unobservable variables and measurement error. Journal of Marketing Research, 18(1), 39-50.

https://doi.org/10.1177/002224378101800104

Garmendia, P., Topa, G., Herrador, T., \& Hernández, M. (2019). Does death anxiety moderate the adequacy of retirement savings? Empirical Evidence from 40-plus clients of Spanish financial advisory firms. International Journal of Financial Studies, 7(3), 38. https://doi.org/10.3390/ijfs7030038

Glymour, M. M., Avendano, M., \& Kawachi, I. (2014). Socioeconomic status and health. In L. F. Berkman, I. Kawachi, \& M. M. Glymour (Eds.), Social epidemiology (2 ed., pp. 17-63). Oxford University Press. https://doi.org/10.1093/med/9780195377903.003.0002

Gold, A. H., Malhotra, A., \& Segars, A. H. (2001). Knowledge management: an organizational capabilities perspective. Journal of Management Information Systems, 18(1), 185-214. https://doi.org/10.1080/07421222.2001.11045669

Goldstein, D. G., Johnson, E. J., \& Sharpe, W. F. (2008). Choosing outcomes versus choosing products: Consumer-focused retirement investment advice. Journal of Consumer Research, 35(3), 440-456. https://doi.org/10.1086/589562 
Gutierrez, H. C., \& Hershey, D. A. (2014). Age differences in expected satisfaction with life in retirement. International Journal of Aging \& Human Development, 78(2), 93-114. https://doi.org/10.2190/AG.78.2.a

Hair Jr, J. F., Hult, G. T. M., Ringle, C., \& Sarstedt, M. (2016). A primer on partial least squares structural equation modeling (PLS-SEM). Sage Publications. https://doi.org/10.15358/9783800653614

Hauff, J. C., Carlander, A., Gärling, T., \& Nicolini, G. (2020). Retirement financial behaviour: How important is being financially literate? Journal of Consumer Policy, 43, 543-564. https://doi.org/10.1007/s10603-019-09444-x

Heikka, T., \& Carayannis, E. G. (2019). Three stages of innovation in participatory journalism - coinitiating, co-sensing, and co-creating news in the Chicago school cuts case. Journal of the Knowledge Economy, 10(2), 437-464. https://doi.org/10.1007/s13132-017-0466-0

Herrador-Alcaide, T. C., \& Ríos-Sastre, S. (2017). The importance of Financial Culture and its treatment in academic research on finance, auditing and accounting. In S. C. Rambaud, \& R. de Pablo Redondo. Avances y retos en economía financiera y empresarial: ensayos en homenaje al profesor Andrés de Pablo López (pp. 207-222). Editorial Centro de Estudios Ramón Areces, S. A., Madrid.

Hershey, D. A., \& Mowen, J. C. (2000). Psychological determinants of financial preparedness for retirement. Gerontologist, 40, 687-697. https://doi.org/10.1093/geront/40.6.687

Hershey, D. A., Henkens, K., \& Van Dalen, H. P. (2010). Aging and financial planning for retirement: interdisciplinary influences viewed through a cross-cultural lens. International Journal of Aging \& Human Development, 70(1), 1-38. https://doi.org/10.2190/AG.70.1.a

Hershey, D. A., Jacobs-Lawson, J. M., McArdle, J. J., \& Hamagami, F. (2007). Psychological foundations of financial planning for retirement. Journal of Adult Development, 14(1-2), 26-36. https://doi.org/10.1007/s10804-007-9028-1

Hershey, D. A., Jacobs-Lawson, J. M., \& Austin, J. T. (2013). Effective financial planning for retirement. In M. Wang (Ed.), The Oxford handbook of retirement (pp. 402-430). Oxford University Press, Inc. https://doi.org/10.1093/oxfordhb/9780199746521.013.0133

Hershey, D. A., Walsh, D. A., Brougham, R., Carter, S., \& Farrell, A. (1998). Challenges of training pre-retirees to make sound financial planning decisions. Educational Gerontology: An International Quarterly, 24(5), 447-470. https://doi.org/10.1080/0360127980240503

Hershfield, H. E., Goldstein, D. G., Sharpe, W. F., Fox, J., Yeykelis, L., Carstensen, L. L., \& Bailenson, J. N. (2011). Increasing saving behavior through age-progressed renderings of the future self. Journal of Marketing Research, 48(SPL), S23-S37. https://doi.org/10.1509/jmkr.48.SPL.S23

Hoffmann, A. O., \& Plotkina, D. (2020). Why and when does financial information affect retirement planning intentions and which consumers are more likely to act on them? Journal of Business Research, 117, 411-431. https://doi.org/10.1016/j.jbusres.2020.06.023

Hu, L. T., \& Bentler, P. M. (1999). Cutoff criteria for fit indexes in covariance structure analysis: Conventional criteria versus new alternatives. Structural Equation Modeling, 6, 1-55. https://doi.org/10.1080/10705519909540118

Huston, S. J. (2010). Measuring financial literacy. Journal of Consumer Affairs, 44(2), 296-316. https://doi.org/10.1111/j.1745-6606.2010.01170.x

Jacobs-Lawson, J. M., \& Hershey, D. A. (2005). Influence of future time perspective, financial knowledge, and financial risk tolerance on retirement saving behaviors. Financial Services Review, 14(4), 331.

Johnson, D. J., Shenaq, D., \& Thakor, M. (2016). Making the end as good as the beginning: Financial planning and retirement for women plastic surgeons. Plastic and Reconstructive Surgery, 138(4), 935-940. https://doi.org/10.1097/PRS.0000000000002556

Joo, S. H., \& Grable, J. E. (2005). Employee education and the likelihood of having a retirement savings program. Financial Counseling and Planning, 16(1), 37-49. 
Kahn, K. (2018). Reconnecting work and wealth. A Report from the 2017 Aspen Institute Economic Security. The Aspen Institute Economic Security.

Kalmi, P., \& Ruuskanen, O. P. (2017). Financial literacy and retirement planning in Finland. Journal of Pension Economics \& Finance, 17(3), 335-362. https://doi.org/10.1017/S1474747217000270

Karlsson, B. S., \& Allwood, C. M. (2016). What is the correct answer about the dress' colors? Investigating the relation between optimism, previous experience, and answerability. Frontiers in Psychology, 7, 1808. https://doi.org/10.3389/fpsyg.2016.01808

Kendig, H., Loh, V., O'Loughlin, K., Byles, J., \& Nazroo, J. Y. (2016). Pathways to well-being in later life: Socioeconomic and health determinants across the life course of Australian baby boomers. Journal of Population Ageing, 9(1-2), 49-67. https://doi.org/10.1007/s12062-015-9132-0

Kim, K. T., Pak, T. Y., Shin, S. H., \& Hanna, S. D. (2018). The relationship between financial planner use and holding a retirement saving goal: A propensity score matching analysis. Financial Planning Review, 1(1-2), e1008. https://doi.org/10.1002/cfp2.1008

Kimball, M. S., \& Shumway, T. (2010). Investor sophistication and the home bias, diversification, and employer stock puzzles. Knowledge Economy, 10(2), 437-464. https://doi.org/10.2139/ssrn.1572866

Kopanidis, F. Z., Robinson, L. J., \& Reid, M. (2017). To stay or to go? Postretirement housing choices of single baby boomer women. Journal of Women \& Aging, 29(5), 417-427. https://doi.org/10.1080/08952841.2016.1213109

Koposko, J. L., Kiso, H., Hershey, D. A., \& Gerrans, P. (2016). Perceptions of retirement savings relative to peers. Work, Aging and Retirement, 2(1), 65-72. https://doi.org/10.1093/workar/wav019

Kramer, M. M. (2012). Financial advice and individual investor portfolio performance. Financial Management, 41(2), 395-428. https://doi.org/10.1111/j.1755-053X.2012.01185.X

Leung, C. S., \& Earl, J. K. (2012). Retirement resources inventory: Construction, factor structure and psychometric properties. Journal of Vocational Behavior, 81(2), 171-182. https://doi.org/10.1016/j.jvb.2012.06.005

Loke, V., Choi, L., \& Libby, M. (2015). Increasing youth financial capability: An evaluation of the MyPath savings initiative. Journal of Consumer Affairs, 49(1), 97-126. https://doi.org/10.1111/joca.12066

Lusardi, A., \& Mitchell, O. S. (2009). How ordinary consumers make complex economic decisions: Financial literacy and retirement readiness (NBER Working Paper 15350). National Bureau of Economic Research. https://doi.org/10.3386/w15350

Lusardi, A., Mitchell, O. S., \& Oggero, N. (2020). Debt and financial vulnerability on the verge of retirement. Journal of Money, Credit and Banking, 52(5), 1005-1034. https://doi.org/10.1111/jmcb.12671

Lusardi, A., \& Mitchell, O. S. (2014). The economic importance of financial literacy: Theory and evidence. Journal of Economic Literature, 52(1), 5-44. https://doi.org/10.1257/jel.52.1.5

Magendans, J., Gutteling, J. M., \& Zebel, S. (2016). Psychological determinants of financial buffer saving: The influence of financial risk tolerance and regulatory focus. Journal of Risk Research, 20(6), 1-18. https://doi.org/10.1080/13669877.2016.1147491

Major, R. J., Whelton, W. J., Schimel, J., \& Sharpe, D. (2016). Older adults and the fear of death: The protective function of generativity. Canadian Journal on Aging/La Revue Canadienne du Vieillissement, 35(2), 261-272. https://doi.org/10.1017/S0714980816000143

Marsden, M., Zick, C. D., \& Mayer, R. N. (2011). The value of seeking financial advice. Journal of Family and Economic Issues, 32(4), 625-643. https://doi.org/10.1007/s10834-011-9258-Z

Nam, Y., \& Loibl, C. (2020). Financial capability and financial planning at the verge of retirement age. Journal of Family and Economic Issues. https://doi.org/10.1007/s10834-020-09699-4

Neukam, K. A., \& Hershey, D. A. (2003). Financial inhibition, financial activation, and saving for retirement. Financial Services Review, 12(1), 19. 
Niu, Y., \& Gibson, H. J. (2020). Leisure, international retirement migration, and retirement adjustment: insights from the best exotic marigold hotel movies. Leisure Studies, 39(3), 404-416. https://doi.org/10.1080/02614367.2020.1731840

Osborne, J. W. (2016). An existential perspective on death anxiety, retirement, and related research problems. Canadian Journal on Aging/La Revue Canadienne du Vieillissement, 36, 246-255. https://doi.org/10.1017/S0714980816000465

Petkoska, J., \& Earl, J. K. (2009). Understanding the influence of demographic and psychological variables on retirement planning. Psychology and Aging, 24(1), 245. https://doi.org/10.1037/a0014096

Puri, M., \& Robinson, D. T. (2007). Optimism and economic choice. Journal of Financial Economics, 86(1), 71-99. https://doi.org/10.1016/j.jfineco.2006.09.003

Purnell, J. Q., Simon, S., Zimmerman, E. B., Camberos, G. J., \& Fields, R. (2016). Policy implications of social determinants of health. In A. Eyler, J. Chriqui, S. Moreland-Russell \& R. Brownson (Eds.), Prevention, policy, and public health (pp. 93-116). Oxford University Press. https://doi.org/10.1093/med/9780190224653.003.0005

Resende, M., \& Zeidan, R. (2015). Psychological biases and economic expectations: Evidence on industry experts. Journal of Neuroscience, Psychology, and Economics, 8(3), 160-172. https://doi.org/10.1037/npe0000043

Richter, N. F., Cepeda-Carrión, G., Roldán Salgueiro, J. L., \& Ringle, C. M. (2016). European management research using partial least squares structural equation modeling (PLS-SEM). European Management Journal, 34(6), 589-597. https://doi.org/10.1016/j.emj.2016.08.001

Ringle, C., Wende, S., \& Becker, J. (2015). SmartPLS 3. Bönningstedt: SmartPLS. http://www.smarpls.com.

Ruberton, P. M., Gladstone, J., \& Lyubomirsky, S. (2016). How your bank balance buys happiness: The importance of "cash on hand" to life satisfaction. Emotion, 16(5), 575-580. https://doi.org/10.1037/emo0000184

Sharpe, D. L., Anderson, C., White, A., Galvan, S., \& Siesta, M. (2007). Specific elements of communication that affect trust and commitment in the financial planning process. Journal of Financial Counseling and Planning, 18(1).

Sherraden, M. S., Johnson, L., Guo, B., \& Elliott III, W. (2011). Financial capability in children: Effects of participation in a school-based financial education and savings program. Journal of Family and Economic Issues, 32(3), 385-399. https://doi.org/10.1007/s10834-010-9220-5

Sousa, I. C., Ramos, S., \& Carvalho, H. (2019). Age-diversity practices and retirement preferences among older workers: A moderated mediation model of work engagement and work ability. Frontiers in Psychology, 10, 1937. https://doi.org/10.3389/fpsyg.2019.01937

Stawski, R. S., Hershey, D. A., \& Jacobs-Lawson, J. M. (2007). Goal clarity and financial planning activities as determinants of retirement savings contributions. The International Journal of Aging and Human Development, 64(1), 13-32. https://doi.org/10.2190/13GK-5H72-H324-16P2

Swift, S. L., Bailey, Z., \& Al Hazzouri, A. Z. (2019). Improving the epidemiological understanding of the dynamic relationship between life course financial well-being and health. Current Epidemiology Reports, 6(1), 28-33. https://doi.org/10.1007/s40471-019-0181-4

Taft, M. K., Hosein, Z. Z., Mehrizi, S. M. T., \& Roshan, A. (2013). The relation between financial literacy, financial wellbeing and financial concerns. International Journal of Business and Management, 8(11), 63. https://doi.org/10.5539/ijbm.v8n11p63

Tamborini, C. R., \& Kim, C. (2019). Are you saving for retirement? Racial/ethnic differentials in contributory retirement savings plans. The Journals of Gerontology: Series $B$.

https://doi.org/10.1093/geronb/gbz131

Topa, G., \& Herrador-Alcaide, T. (2016). Procrastination and financial planning for retirement: A moderated mediation analysis. Journal of Neuroscience, Psychology, and Economics, 9(3-4), 169.

https://doi.org/10.1037/npe0000065 
Topa, G., \& Pra, I. (2018). Retirement adjustment quality: optimism and self-efficacy as antecedents of resource accumulation. Applied Research in Quality of Life, 13(4), 1015-1035. https://doi.org/10.1007/s11482-017-9571-2

Topa, G., Lunceford, G., \& Boyatzis, R. E. (2018). Financial planning for retirement: a psychosocial perspective. Frontiers in Psychology, 8, 2338. https://doi.org/10.3389/fpsyg.2017.02338

Topa, G., Moriano, J. A., Depolo, M., Alcover, C. M., \& Morales, J. F. (2009). Antecedents and consequences of retirement planning and decision-making: A meta-analysis and model. Journal of Vocational Behavior, 75(1), 38-55. https://doi.org/10.1016/j.jvb.2009.03.002

United Nations. (2019). United Nations Development Programme. Human Development Reports. http://hdr.undp.org/en/data

Van Dalen, H. P., \& Henkens, K. (2005). The double standard in attitudes toward retirement - The case of the Netherlands. The Geneva Papers on Risk and Insurance-Issues and Practice, 30(4), 693-710. https://doi.org/10.1057/palgrave.gpp.2510045

Vidová, J., \& Sika, P. (2020). Christmas allowance as a non-system tool for sustainability of quality of life of Slovak seniors. Sustainability, 12(9), 3810. https://doi.org/10.3390/su12093810

Wang, M., \& Shi, J. (2014). Psychological research on retirement. Annual Review of Psychology, 65, 209-233. https://doi.org/10.1146/annurev-psych-010213-115131

Wang, M., \& Wanberg, C. R. (2017). 100 years of applied psychology research on individual careers: From career management to retirement. Journal of Applied Psychology, 102(3), 546-563. https://doi.org/10.1037/apl0000143

Weckroth, M., Kemppainen, T., \& Dorling, D. (2017). Socio-economic stratification of life satisfaction in Ireland during an economic recession: A repeated cross-sectional study using the European Social Survey. Irish Journal of Sociology. https://doi.org/10.1177/0791603517697326

Yeung, D. Y. (2013). Is pre-retirement planning always good? An exploratory study of retirement adjustment among Hong Kong Chinese retirees. Aging \& Mental Health, 17(3), 386-393.

https://doi.org/10.1080/13607863.2012.732036

Zaniboni, S. (2015). The interaction between older workers' personal resources and perceived age discrimination affects the desired retirement age and the expected adjustment. Work, Aging and Retirement, 1(3), 266-273. https://doi.org/10.1093/workar/wav010

Zaniboni, S., Sarchielli, G., \& Fraccaroli, F. (2010). How are psychosocial factors related to retirement intentions? International Journal of Manpower, 31(3), 271-285.

https://doi.org/10.1108/01437721011050576 